\title{
Subchronic exposure of rats to sublethal dose of microcystin-YR induces DNA damage in multiple organs
}

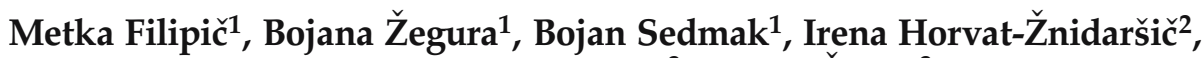 \\ Aleksandra Milutinovič ${ }^{2}$, Dušan Šuput ${ }^{2}$ \\ ${ }^{1}$ National Institute of Biology, Department for Genetic Toxicology \\ and Cancer Biology, Ljubljana, Slovenia; ${ }^{2}$ Medical Faculty, Institute of Pathophysiology, \\ University of Ljubljana, Ljubljana, Slovenia
}

\begin{abstract}
Background. Microcystins (MCs) are cyclic heptapeptides that are considered to be liver specific toxins. They are potent tumour promoters and recent studies indicate that they are also genotoxic. In this study we measured DNA damage in lymphocytes, liver, kidney (cortex and medulla), lung, spleen and brain cells of male Fisher F344 rats that were exposed to sublethal dose (every second day $10 \mu \mathrm{g} / \mathrm{kg}$ b.w.; i.p) of microcystin-YR (MCYR) for one month.

Methods. At the end of exposure the animals were sacrificed, the lymphocytes were isolated from blood taken from jugular vein, liver cells were obtained by perfusion with collagenase A and the cells from other organs were isolated by incubating small tissue pieces with collagenase A. The DNA damage in isolated cells was measured with the single cells gel electrophoresis (SCGE) also called the comet assay.

Results. A significant increase of the \% tail DNA in MCYR-exposed animals compared to the nonexposed control ones was observed in brain (2.5 fold), liver (2.1 fold), kidney medulla (1.9 fold), kidney cortex (1.8 fold) and lung (1.7 fold) cells, while the DNA from lymphocytes and spleen cells was not affected.

Conclusion. This study demonstrated that subchronic exposure to sublethal doses of MCs can induce systemic genotoxicity in mammals, and it affects not only the liver but also other vital organs.
\end{abstract}

Key words: DNA damage; comet assay; cyanobacteria; bacterial toxins; rats, inbred F344

\section{Introduction}

Microcystins (MCs) comprise a family of more than 60 structurally related hepato-

Received 21 March 2007

Accepted 29 March 2007

Correspondence to: Assist. Prof. Metka Filipič, Ph.D., National Institute of Biology, Večna pot 111, 1000 Ljubljana, Slovenia. Phone: +386 14233 388; Fax: +38612573 847; E-mail: metka.filipic@nib.si toxins produced by cyanobacterial species. ${ }^{1}$ Among them microcystin-LR (MC-LR) is the most toxic. The variable amino acids of the most common microcystin variants, MC-LR, $\mathrm{RR}$ and $\mathrm{YR}$ are leucine (L), arginine (R) and tyrosine $(\mathrm{Y})$ (Figure 1). Toxic cyanobacteria found in eutrophic, freshwater, municipal and residential water supplies represent an increasing environmental hazard in many parts of the world. ${ }^{2,3}$ Cyanobacterial blooms in surface water have been associated with 


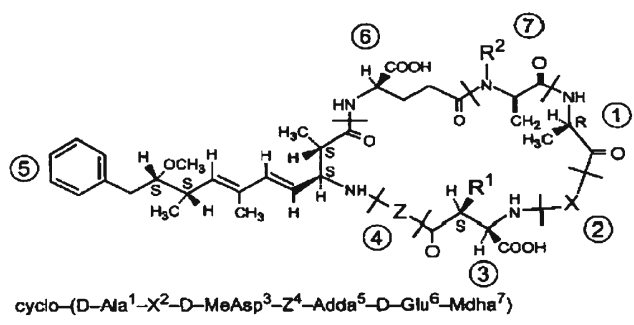

Figure 1. The structure of microcystins. The amino acids at the positions $X$ and $Z$ are variable. Microcystin$\mathrm{YR}(\mathrm{X}=$ tryptophyan, $\mathrm{Z}=$ arginin); microcystin-LR $(\mathrm{X}=$ leucin, $\mathrm{Z}=$ arginin).

poisoning and death of wildlife and domestic animals. ${ }^{2}$ In humans MCs intoxication caused symptoms such as nausea/vomiting, weakness, skin irritation, and illnesses ranging from gastroenteritis and pneumonia to hepatoenteritis. ${ }^{4}$ The most severe human intoxication happened in 1996 in Brazil, where 60 of 126 dialysis patients died of liver failure due to cyanobacterial contamination of the water used for dialysis. ${ }^{5}$ Epidemiological studies have suggested that MCs are one of the risk factors for the high incidence of primary liver cancer in certain areas of China, where people have consumed pond-ditch water contaminated with cyanobacteria. ${ }^{6}$

Although MCs accumulate predominantly in the liver, they have also been detected in other organs. ${ }^{7,8}$ Liver is the main target organ for MCs toxicity, because they are entering the cells through the multispecific transport system for bile acids ${ }^{9,10}$ and the predilection for hepatic damage by MCs thus probably depends on the high concentration of these transporters in the hepatocyte membrane. However, several in vitro studies showed that MCs exert toxic effects in different non-hepatic cell lines. Microcystin-LR induced toxic effects in epidermoid carcinoma cells (KB) ${ }^{11}$ and apoptosis in human endothelial and epithelial cells and in rat fibroblasts and promyelocytes. ${ }^{12}$

MCs are potent inhibitors of protein phosphatase 1 and $2 \mathrm{~A}$, leading to the in- creased protein phosphorylation, which is directly related to their cytotoxic and tumor-promoting activity. ${ }^{13,14}$ Apart from the inhibition of protein phosphatases, the oxidative stress also plays a significant role in the pathogenesis of microcystin toxicity. MCs can induce intracellular reactive oxygen species (ROS) formation, cell injury and lipid peroxidation. ${ }^{15-18}$ There is increasing evidence that MCs are also genotoxic. It has been reported that MCs induce DNA strand breaks in liver cells in vivo $0^{19,20}$ and in vitro. ${ }^{21,22}$ Several in vitro studies showed, that MCs induced DNA strand breaks also in different types of non-hepatic cells including baby hamster kidney cells, mouse embryo primary fibroblasts ${ }^{23}$ and human peripheral lyphocytes. ${ }^{24}$ In addition, they induced micronuclei formation and loss of heterozygosity in human lymphoblastoid TK 6 cells, ${ }^{25}$ and base substitution mutations at K-ras codon 12 in human RSa cells. ${ }^{26}$

The aim of our study was to explore if a subchronic exposure of rats to a sublethal dose of microcystine-YR (MCYR) induces DNA strand breaks in different organs. The DNA damage was measured by single cell gel electrophoresis (SCGE), also called the comet assay, which is a very sensitive method for detecting DNA double- and single-strand breaks, alkali labile sites, DNADNA and DNA-protein cross links, and single-strand breaks associated with the incomplete excision repair. ${ }^{27}$ The in vivo comet assay is being increasingly used in genotoxicity testing because of its applicability to various tissues and its sensitivity to low levels of DNA damage.

\section{Materials and methods}

\section{Animals}

Male Fischer F 344 rats weighing 200 to $250 \mathrm{~g}$ were housed in standard plastic 
cages with sawdust cover on the floor. They were maintained on a $12 \mathrm{~h}$ light-dark cycle (light on: $07.00-19.00 \mathrm{~h}$ ) in a colony room controlled at $22-24^{\circ} \mathrm{C}$, with free access to rodent pellets and tap water. The animals were maintained following the guidelines in the Slovenian Law for Animal Health Protection and Instructions for Granting Permission for Animal Experimentation for Scientific Purposes.

\section{Toxin and experimental design}

MCYR was isolated from cyanobacterial bloom (Microcystis aeruginosa) from an artificial recreational pond (Koseze, Ljubljana, Slovenia) according to the method of Harada et al., ${ }^{28}$ as described previously. ${ }^{3}$ The toxin was dissolved at a final concentration of $2.7 \mu \mathrm{g} / \mathrm{ml}$ in the vehicle solution of ethanol $(0.8 \%)$ and methanol $(0.2 \%)$ in physiological saline $(0.9 \%)$.

The experimental rats (7 animals) were applied i.p. with $10 \mu \mathrm{g} / \mathrm{kg}$ b.w. MCYR in a volume of $3.7 \mathrm{ml} / \mathrm{kg}$, every second day during the period of 30 days. The control group (4 animals) received $3.7 \mathrm{ml} / \mathrm{kg}$ i.p. vehicle (the mixture of ethanol and methanol dissolved in physiological saline). At the end of the experiment the animals were sacrificed using $\mathrm{CO}_{2}$ anaesthesia. At sacrifice, blood, liver, kidneys (cortex and medulla were separated), lung, spleen and brain tissues were collected in order to proceed the comet assay as detailed below.

\section{Cell isolation and preparation of single cell suspension}

Blood was collected from jugular vein on heparin from anesthetized animals just before they were sacrificed. The lymphocytes were then isolated using Ficoll-Paque ${ }^{\mathrm{TM}}$ plus (Amersham Pharmacia Biotech $A B$, Sweden) and suspended in RPMI 1640 medium. The single cell suspensions of liver cells was prepared by liver perfusion with collagenase $\mathrm{A}$ as described. ${ }^{29}$ The single cell suspensions from kidney (cortex and medulla were separated), lung (inferior lobe), spleen and brain (distal part) were prepared with a non-perfusion procedure using collagenase A. Briefly, partial tissue was cut from each isolated organ, washed twice with chilled PBS solution, gently cut in small pieces and incubated in the solution of $0,5 \mathrm{mg} / \mathrm{ml}$ collagenase A (Sigma) for 20 minutes. The cell suspension was then gently aspirated several times with the pipette and transferred into centrifuge tube with $2 \mathrm{ml}$ Eagle's essential minimal medium (Sigma) containing 10\% fetal bovine serum (FBS) to inactivate collagenase $\mathrm{A}$. The cell suspension was then centrifuged for 10 minutes at $1000 \mathrm{rpm}$. The collagenase supernatant was removed and the precipitate was re-suspended in Eagle's essential minimal medium (Sigma) supplemented with $10 \%$ FBS. The viability of cells was assessed using trypan blue exclusion assay. ${ }^{30}$

\section{Comet assay}

The assay was performed as described by Singh et al. ${ }^{31} 30 \mu \mathrm{l}$ of single cell suspension $(\approx 400,000$ cells $/ \mathrm{ml})$ was mixed with $70 \mu \mathrm{l}$ of $1 \%$ low melting point agarose and added to fully frosted slides that had been covered with a layer of $1 \%$ normal melting point agarose. The cells were then lysed (2.5 M NaOH, pH 10, 0.1 M EDTA, 0.01 M Tris and $1 \%$ Triton $\mathrm{X}-100$ for $1 \mathrm{hr}$ at $4{ }^{\circ} \mathrm{C}$ ), rinsed with distilled water, placed in the electrophoresis solution $(300 \mathrm{mM} \mathrm{NaOH}$, $1 \mathrm{mM}$ EDTA, pH 13) for 20 minutes to allow DNA unwinding, and electrophoresed for 20 minutes at $25 \mathrm{~V}$ and $300 \mathrm{~mA}$. Finally, the slides were neutralized with $0.4 \mathrm{M}$ Tris buffer (pH 7.5), and the DNA stained with ethidium bromide $(5 \mu \mathrm{g} / \mathrm{ml})$. Two slides were prepared per tissue per animal and 50 randomly selected nuclei per slide were 
captured under the fluorescence microscope (Olympus) and the images analyzed with image analysis software (VisCOMET, TillPhotonics, Germany). The \% tail DNA was used to measure DNA damage.

\section{Statistical Analysis}

One-way analysis of variance (ANOVA, Kruskal-Wallis) was used to analyze the differences between treated and control animals. A Dunnet test was used to compare mean values of \% tail DNA; $\mathrm{p}<0.05$ was considered as statistically significant.

\section{Results}

In this study we recorded DNA damage in liver, kidney medulla and cortex, lung, brain and spleen cells and in lymphocytes of rats that were treated with sublethal dose of MCYR (10 $\mu \mathrm{g} / \mathrm{kg}$ b.w.; i.p) every second day during the period of 30 days. The control rats received the vehicle (mixture of $0.8 \%$ etanol and $0.2 \%$ methanol dissolved in $0.9 \%$ physiological saline). The control animals appeared healthy and free from pathological signs, while animals that have received MCYR appeared less active and the fur was less shiny, suggesting a systemic toxic effect. After sacrifice and autopsy, no macroscopic evidence of degenerative processes was observed in any of the experimental animals. The cell viability after the isolation from organs was found to be more than $80 \%$ in all animals (data not shown).

A significant increase of DNA damage in MCYR treated animals compared to the control was detected in liver, kidney medulla and cortex, lung and brain, while no DNA damage was detected in spleen and lymphocytes (Figure 1 and Table 1). From the ratio between mean value of the \% tail DNA of the cells from the treated animals and that of the control animals it can be seen that the highest level of DNA damage was induced in brain, followed by liver $>$ kidney medulla $>$ kidney cortex $>$ lung (Table 1).

The data of the \% tail DNA were further analyzed in terms of the distribution of single cells according to the extent of DNA damage in the whole population of analyzed cells from each organ (Figure 1). The cells isolated from vehicle treated control animals had relatively uniform low DNA damage; however, the mean values of the percent comet tail DNA were different for different organs. The cells isolated from liver, kidney medulla, kidney cortex, lung and brain of the treated animals showed a heterogeneous distribution ranging from cells with low to cells with high DNA damage. The majority of the cells had higher \% tail DNA compared to the distribution of \% tail DNA in cells isolated from the corresponding organ of the control animals.

\section{Discussion}

Acute hepatotoxic effects of MCs are well explored, while their effects on other organs have been neglected for a long time because the acute hepatotoxic effects caused by lethal intoxication are dominant and sufficient to cause the death of the animals before effects on other organs can be observed. However, at sublethal chronic intoxication it seems reasonable to expect that MCs could cause effects also in other organs. Recently Milutinović et al. ${ }^{32}$ reported that the chronic intoxication of rats with sublethal doses of microcystins MCLR and MCYR induced kidney injury.

In the present study we investigated the in vivo genotoxicity of MCYR in some organs and tissues of rats by measuring the DNA damage with the comet assay. The organs examined were liver, which is the target organ and kidney, lung, brain, spleen and lymphocytes which are considered as non- 
Table 1. The DNA damage in rat organs after 30 day exposure to sublethal dose $(10 \mu \mathrm{g} / \mathrm{kg}$ b.w. i.p. every second day) of MCYR

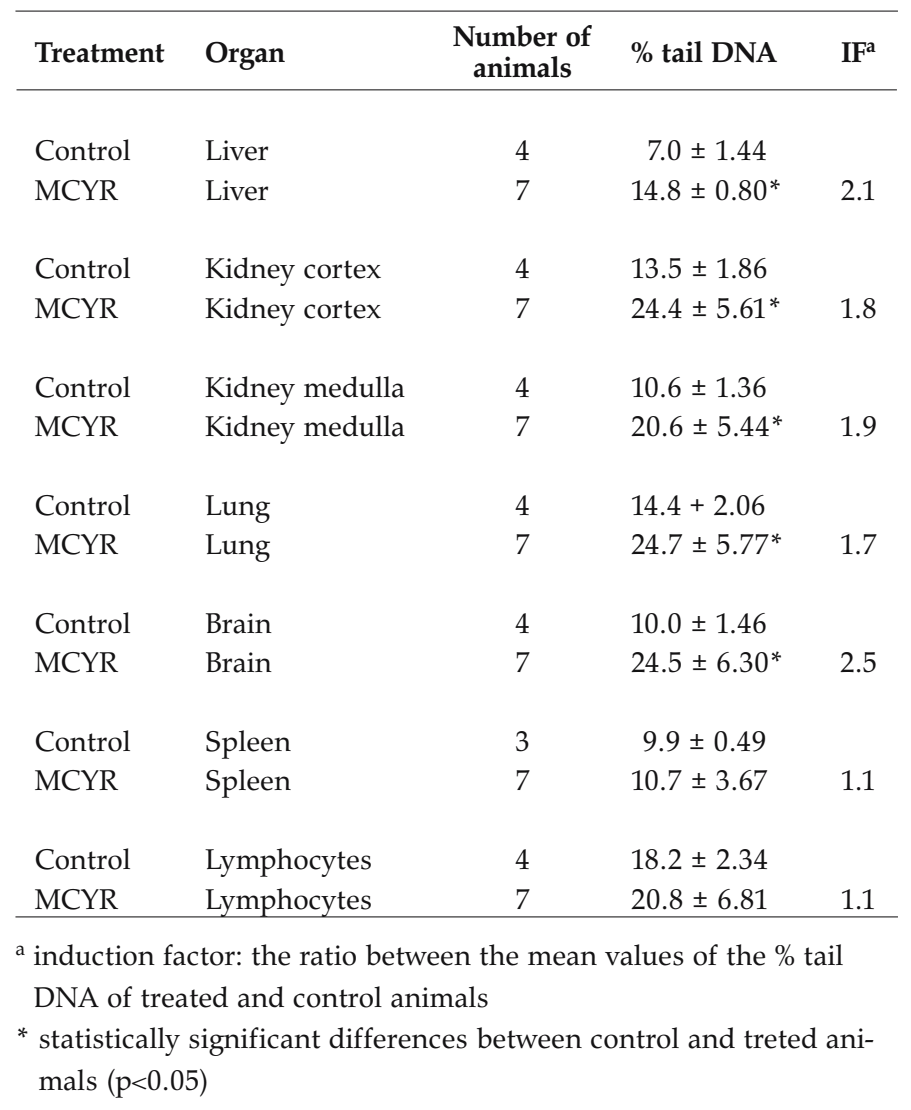

The acute exposure of rats to MCLR resulted in a decrease of the endogenous antioxidant defence system together with an increase of lipid peroxidation in liver and in kidney. ${ }^{33}$ This supports the assumption that the DNA damage of liver and kidney cells we observed in our study was mediated by oxidative stress. The extent of DNA damage in liver cells was higher than in kidney cells, which is in line with the above mentioned study of Moreno et al., 33 who showed that antioxidant enzymes were significantly decreased in liver, while minor decrease was found in kidney, indicating different organ susceptibility to adverse effects of MCs.

An interesting finding of this study was the highest level of DNA target organs. The results clearly showed that prolonged exposure of rats to sublethal dose of MCYR induced DNA damage not only in liver, but also in brain, kidney and lung cells. The observed DNA damage was most likely due to MCLY induced oxidative stress in affected organs. This assumption is based on: i) demonstration that the oxidative stress plays a significant role in the pathogenesis of chronic exposure to MCLR; ${ }^{17}$ ii) reactive oxygen species (ROS) are known to induce DNA strand breaks, which can be readily detected with the comet assay and iii) MCLR induced DNA strand breaks in human hepatoma HepG2 cells were ROS mediated. ${ }^{18}$ damage in brain cells. The result corroborates recent results of Maidana et al. ${ }^{34}$ who showed that intrahippocampal infusion of microcystin raw extract induced oxidative stress and DNA damage in cells isolated from hippocampus. The question is how MCs are transported through the body and absorbed by non hepatic tissue. Fisher et $a{ }^{35}$ reported that members of organic anion transporting polypeptide super family involved in MCs uptake (including the human OATP1A2 transporter) are expressed in liver and in endothelial cells of the bloodbrain barrier. This explains brain as the target of MCs toxicity. The low antioxidant and DNA repair capacity of the brain could 

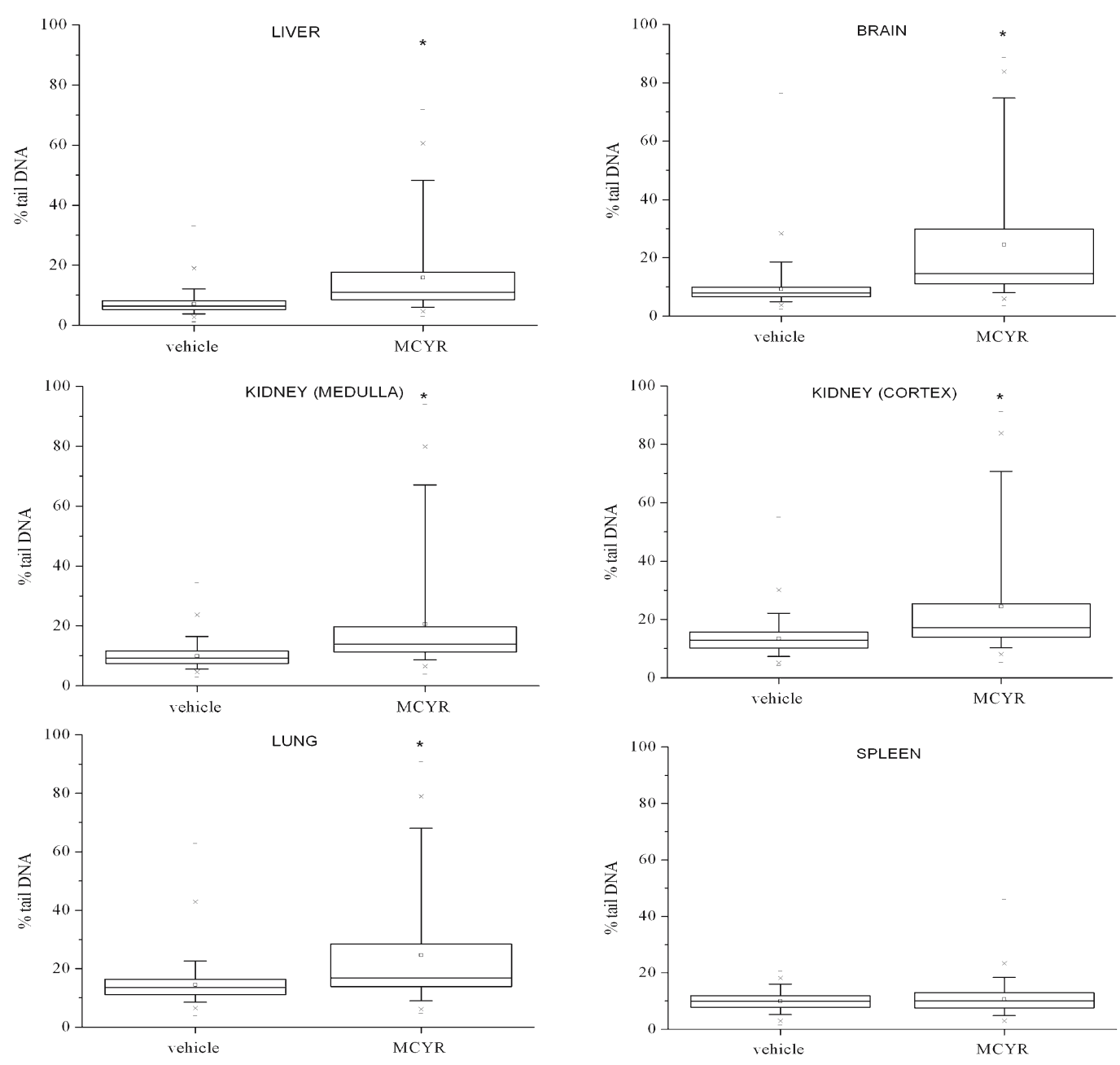

Figure 2. Distribution of the level of DNA damage in rat liver, kidney medulla, kidney cortex, lung, brain, spleen and lymphocytes after sub-chronic exposure to MCLY. The experimental group of rats $(n=7)$ received, every second day during the period of 30 days, 10 $\mu \mathrm{g} / \mathrm{kg}$ i.p. MCYR, the control group $(\mathrm{n}=4)$ received vehicle. The extent of DNA damage in isolated cells was measured with the comet assay. The level of DNA strand breaks is expressed as \% tail DNA. One hundred cells were analyzed per organ per animal. The polled data are presented as quantile box plots. The edges of

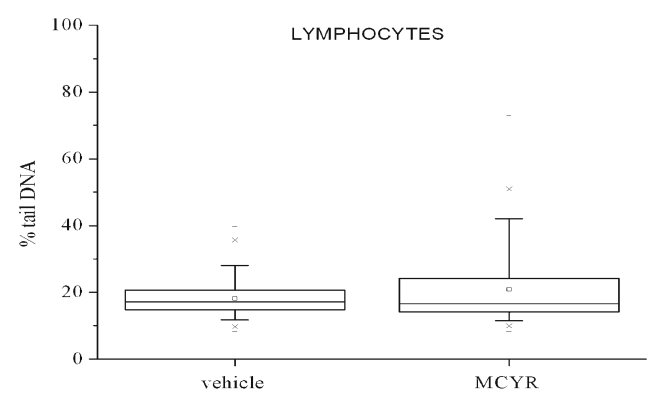
the box represent the 25 th and 75 th percentiles, the median is a solid line through the box, mean values are represented as square $(\square)$, and the error bars represent the $95 \%$ confidence intervals. ${ }^{*}$ denotes a significant difference between MCLY-treated groups and control (Kruskal-Wallis test, $P<0.05$ ). 
be the explanation for the highest level of DNA damage in the brain. ${ }^{36}$

MCYR induced DNA damage also in lung, however, little is known about the effects of MCs on lung. The only report we are aware of is by Gupta et al. ${ }^{37}$ who found that in mice after the acute exposure to MCLR, MCRR and MCYR induced pulmonary inflammation, congestion and haemorrhage. Interestingly no DNA damage was observed in the haematopoietic system; spleen and lymphocytes. An in vitro study has shown that MCs induce DNA damage in human lymphocytes, ${ }^{24}$ however, no in vivo study of the effects of MCs on lymphocytes is available.

In conclusion, the subchronic administration of sublethal dose of MCYR induced DNA strand breaks that were observed in brain liver, kidney, and lung confirming the genotoxic potential of this toxin. However, the correlation of these findings with carcinogenicity of MCs needs to be further investigated.

\section{Acknowledgments}

This study was supported by the Slovenian Research Agency, program \#P1-245 and project \# J1-6712. We thank Professor Tamara T. Lah for valuable suggestions and discussion and Prof. Roger Pain for critical reading of the manuscript.

\section{References:}

1. McElhiney J, Lawton LA. Detection of the cyanobacterial hepatotoxins microcystins. Toxicol Appl Pharmacol 2005; 203: 219-30.

2. Dawson RM. Toxicology of microcystins. Toxicon 1998; 7: 953-62.

3. Sedmak B, Kosi, G. Microcystins in Slovene freshwaters (Central Europe): first report. Nat Toxins 1997; 5: 64-73.
4. Codd GA, Bell SG, Kaya K, Ward CJ, Beattie KA, Metcalf JS. Cyanobacterial toxins, exposure routes and human health. Eur J Physiol 1999; 34: 405-15.

5. Carmichael WW. Azevedo SMFO, An JS, Molica RJR, Jochimsen EM, Lau S, et al. Human fatalities from cyanobacteria: Chemical and biological evidence for cyanotoxins. Environ Health Perspect 2001; 109: 663-8.

6. Ueno $\mathrm{Y}$, Nagata S, Tsutsumi T, Hasegawa A, Watanabe M.F, Park HD, et al. Detection of microcystins, a blue-green algal hepatotoxin, in drinking water sampled in Haimen and Fusui, endemic areas of primary liver cancer in China, by highly sensitive immunoassay. Carcinogenesis 1996; 17: 1317-21.

7. Nishiwaki R, Ohta T, Suoeka E, Suganuma M, Harada KI, Watanebae MF, et al. Two significant aspect of microcystin-LR: specific binding and liver specificity. Cancer Lett 1994; 83: 283-9.

8. Ito E, Kondo F, Harada KI. First report on the distribution of orally administered microcystin-LR in mouse tissue using an immunostaining method. Toxicon 2000; 38: 37-48.

9. Eriksson JE, Gronberg L, Nygård S, Slotte JP, Meriluoto JA. Hepatocellular uptake of 3H-dihydromicrocystin-LR, a cyclic peptide toxin. Biochim Biophy Acta 1990; 1025: 60-6.

10. Carmichael WW, Falconer IR. Diseases related to freshwater blue-green algal toxins and control measures. In: Falconer IR, editor. Algal toxins in seafood and drinking water. London: Academic Press; 1993. p. 187-209.

11. Chong MW, Gu KD, Lam PK, Yang M, Fong WF. Study on the cytotoxicity of microcystin-LR on cultured cells. Chemosphere 2000; 41: 143-7.

12. McDermott CM, Nho CW, Howard W, Holton B. The cyanobacterial toxin, microcysin-LR can induce apoptosis in a variety of cell types. Toxicon 1998; 36: 1981-6.

13. Carmichael WW, Azevedo SM, An JS, Molica RJ, Jochimsen EM, Lau S, Rinehart KL, Shaw GR, Eaglesham GK. Human fatalities from cyanobacteria: chemical and biological evidence for cyanotoxins. Environ Health Perspect 2001; 109: 663-8.

14. Yoshizawa S, Matsushima R, Watanabe MF, Harada K-I, Ichihara A, Carmichael WW, Fujiki H. Inhibition of protein phosphatases by microcystins and nodularin associated with hepatotoxicity. J Cancer Res Clin Oncol 1990; 116: 609-14.

15. Ding W-X, Shen H-M, Ong C-N. Critical role of reactive oxygen species and mitochondrial permeability transition in microcystin-induced rapid apoptosis in rat hepatocytes. Hepatology 2000; 32: 547-55. 
16. Bouaïcha N, Maatouk I. Microcystin-LR and nodularin induce intracellular glutathione alteration, reactive oxygen species production and lipid peroxidation in primary cultured rat hepatocytes. Toxicol Lett 2004; 148: 53-63.

17. Guzman ER, Solter PF. Hepatic oxidative stress following prolonged sublethal microcystin-LR exposure. Toxicol Pathol 1999; 27: 582-8.

18. Žegura B, Lah TT, Filipič M. The role of reactive oxygen species in microcystin-LR-induced DNA damage. Toxicology 2004; 200: 59-68.

19. Rao PV, Bhattacharaya R. The cyanobacteria toxin microcystin-LR induced DNA damage in mouse liver in vivo. Toxicology 1996; 114: 29-36.

20. Maatouk I, Bouaïcha N, Plessis MJ, Perin F. Detection by ${ }^{32} \mathrm{P}$-postlabelling of 8 -oxo-7,8-dihydro-2'-deoxyguanosine in DNA as biomarker of microcystin-LR- and nodularin-induced DNA damage in vitro in primary cultured rat hepatocytes and in vivo in rat liver. Mutat Res 2004; 564 : 9-20.

21. Ding W-X, Shen H-M, Zhu H-G, Lee B-L. Genotoxicity of microcystic cyanobacteria extract of a water source in China. Mutat Res 1999; 442: 69-77.

22. Rao PV, Bhattacharaya R, Parida M M, Jana A M, Bhaskar A S. Freshwater cyanobacterium Microcystis aeruginasa (UTEX 2385) induced DNA damage in vivo and in vitro. Environ Toxicol Pharmacol 1998; 5: 1-6.

23. Žegura B, Sedmak B, Filipič M. Microcystin-LR induces oxidative DNA damage in human hepatoma cell line HepG2. Toxicon 2003; 41: 41-8.

24. Lankoff A, Krzowski L, Glab J, Banasik A, Lisowska $\mathrm{H}$, Kuszewski $\mathrm{T}$, et al. DNA damage and repair in human peripheral blood lymphocytes following treatment with microcystin-LR. Mutat Res 2004; 559: 131-42.

25. Zhan L, Sakamoto H, Sakuraba M, Wu D-S, Zhang L-S, Suzuki T, et al. Genotoxicity of microcystinLR in human lymphoblastoid TK6 cells. Mutat Res 2004; 557: 1-6.

26. Suzuki H, Watanabe MF, Wu Y, Sugita T, Kita K, Sato T, et al. Mutagenicity of microcystin-LR in human RSa cells. Int J Mol Med 1998; 2: 109-12.

27. Tice RR, Agurel, E, Anderson D, Burlinson B., Hartmann A, Kobayashi H, et al. Single cell gel/ comet assay: Guidelines for in vitro and in vivo genetic toxicology testing. Environ Mol Mutagen 2000; 35: 206-21.
28. Harada KI, Matusura K, Suzuki M, Oka H, Watanabe MF, Oishi S, et al. Analysis and purification of toxic peptides from cyanobacteria by reversed-phase high-performance liquid chromatography. J Chromatogr 1988; 448: 275-84.

29. de Sousa G, Delescluse C, Pralavorio M, Perichaud M, Avon M, Lafaurie M, Rahmani R. Toxic effects of several types of antifouling paints in human and rat hepatic or epidermal cells. Toxicol Lett 1998; 96-97: 41-6.

30. Pool-Zobel BL, Guigas C, Klein RG, Neudecker $\mathrm{CH}$, Renner HW, Schnezer, P. Assessment of genotoxic effect by lindane. Food Chem Toxicol 1993; 31: 271-83.

31. Singh NP, McCoy MT, Tice RR, Schneider EL. A simple technique for quantitation of low levels of DNA damage in individual cells. Exp Cell Res 1988; 175: 184-91.

32. Milutinović A, Živin M, Zorc-Pleskovič R, Sedmak B, Suput D. Nephrotoxic effects of chronic administration of microcystins -LR and -YR. Toxicon 2003; 42: 281-8.

33. Moreno I, Pichardo S, Jos A, Gomez-Amores L, Mate A, Vazquez CM, Camean AM. Antioxidant enzyme activity and lipid peroxidation in liver and kidney of rats exposed to microcystin-LR administered intraperitoneally. Toxicon 2005; 45: 395-402.

34. Maidana M, Carlis V, Galhardi FG, Yunes JS, Geracitano LA, Monserrat JM, Barros DM. Effects of microcystins over short- and long-term memory and oxidative stress generation in hippocampus of rats. Chem Biol Interact 2006; 159: 223-34.

35. Fischer WJ, Altheimer S, Cattori V, Meier PJ, Dietrich DR, Hagenbuch B. Organic anion transporting polypeptides expressed in liver and brain mediate uptake of microcystin, Toxicol Appl Pharmacol 2005; 203: 257-63.

36. Walker AP, Bacherald HS. Studies on DNA damage and repair in mammalian brain, J Neurochem 1988; 51: 1394-9.

37. Gupta N, Pant SC, Vijayaraghavan R, Lakshmana Rao PV. Comparative toxicity evaluation of cyanobacterial cyclic peptide toxin microcystin variants (LR, RR, YR) in mice. Toxicology 2003; 188: 28596. 